\section{New Estonian records: mosses}

\section{Kai Vellak $^{1,2}$, Nele Ingerpuu ${ }^{1}$, Heinjo During ${ }^{3}$, Kjell Ivar Flatberg ${ }^{4}$, Mare Leis ${ }^{5}$, Loore Ehrlich $^{6}$, Leiti Kannukene ${ }^{7}$, Tiiu Kupper $^{2}$}

${ }^{1}$ University of Tartu, Institute of Ecology and Earth Sciences, Lai 40, Tartu 51005, Estonia; E-mail:

kai.vellak@ut.ee, nele.ingerpuu@ut.ee

${ }^{2}$ University of Tartu, Natural History Museum, Vanemuise 46, Tartu 51014, Estonia

${ }^{3}$ University of Utrecht, Ecology \& Biodiversity Group, Institute of Environmental Biology, H. R. Kruyt Building, P.O. Box 800.84, 3508 TB Utrecht, The Netherlands

${ }^{4}$ NTNU University Museum, N-7491 Trondheim, Norway ${ }^{5}$ Estonian University of Life Sciences, Institute of Agricultural and Environmental Sciences, Kreutzwaldi 5, Tartu 51014, Estonia

${ }^{6}$ Estonian Museum of Natural History, Lai 29A, Tallinn 10133, Estonia

${ }^{7}$ Tallinn Botanical Garden, Kloostrimetsa tee 52, Tallinn 11913, Estonia

The most recent checklist of Estonian bryophytes was published in 2015 (Vellak et al., 2015). In 2016 four species new to Estonia have been identified, mainly by checking earlier collections in different herbaria. This addition raises the total number of bryophyte species registered in Estonia up to 598.

One species - Hypnum fertile Sendtn., which was evaluated as extinct in Estonia (Vellak et al., 2015), has been found in a new locality. Also a variety new for Estonia - Hypnum cupressiforme var. resupinatum (Taylor) Schimp. has been found on an island.

Here we present the locality data for all new taxa and for the species that has been considered to be extinct in Estonia.

Hypnum ANDoI A.J.E. Sm. [Ando ulmik]

The species was first identified for Estonia in 2016 from a locality in Harju Co., Jõelähtme District, near Kaberneeme village, in a wet clear-cut area, on a granite boulder $\left(59.4953^{\circ} \mathrm{N}\right.$ $25.2900^{\circ} \mathrm{E}$ ), leg. M. Leis, 18 July 2015 , det. L. Hedenäs, N. Ingerpuu, K. Vellak, 27 Jan 2016 (TU169655, duplicates: TAA5004890, TALL D015085, TAM0116497). While the species is quite common in several neighbourhood countries, all Estonian bryophyte herbaria were checked by the authors to find more specimens. And indeed, altogether 12 specimens were found representing eight different localities (TU162043; TU160096; TAM0013296; TAM0102553; TAA5002267; TAA5004901; TAA5004965; TAA5005193; TAA5005231, TALL D015802; TALL D015803; TALL D015804; http://elurikkus.ut.ee/). The specimens had been collected between 1995 and 2015 by M. Leis and L. Kannukene.

A synonym of Hypnum andoi is Hypnum cupressiforme var. mamillatum (Smith, 1981). Girgensohn has listed seven varieties of $H$. cupressiforme in his overview of the Baltic bryoflora (Girgensohn, 1860), but without any exact locality data. By checking his collections of our herbaria we found a specimen collected by him in 1851 from Vasula forest near Tartu, named as Hypnum cupressiforme var. mamillatum (TAA5005240). It is not known whether the species is still present at the locality. This is the southernmost locality for this species in Estonia, other localities lie in North- and WestEstonia. Another specimen (TU171752), named in his "Musci frondosi et hepatici exsiccati" as H. cupressiforme var. mamillatum (no 172), appeared to contain only Cinclidium stygium.

Thus, Hypnum andoi has nine localities in Estonia and is now considered to be sporadically distributed in Estonia (frequency group according to Vellak et al., 2015). All specimens were found to grow on granitic boulders in forests. In other parts of Europe it is said to grow mainly on trunks of trees (Frey et al., 2006), but also on decaying wood (Hedenäs et al., 2014). In Britain and Ireland it is besides tree bark quite common on rocks (Atherton et al., 2010). The species has a circumpolar distribution, with occurrences also in Macaronesia (Dierßen, 2001).

HyPnUm FERTILE Sendtn. [tihe ulmik]

This species was first reported for Estonia in 2007 (Leis \& Kannukene, 2007) by checking collection of K. G. Girgensohn. The species was evaluated as extinct in 2008 (http:/ / elurikkus. ut.ee/) since its locality near Tartu was vanished by the time. In 2016 a new locality for this species was found in Estonia, so its IUCN category should be re-evaluated. The present locality is situated in L-Viru Co., Laekvere District, Tudu- 
soo Nature Reserve, on the trunk of an ash tree $\left(59.0775^{\circ} \mathrm{N} 26.7615^{\circ} \mathrm{E}\right)$, leg. P. Lõhmus, 08 Oct 2016, det. M. Leis, N. Ingerpuu, K. Vellak, 28 Nov 2016 (TAA50005234).

Hypnum fertile has a southern distribution in Europe and it is absent from Scandinavian countries. It has been found growing on rotten trees (Frey et al., 2006), but also on rocks or humus (Dierßen, 2001). The species has been proposed as a candidate for the Red List of European bryophytes (Hodgetts, 2015).

HYPNUM CUPRESSIFORME var. RESUPINATUM (Taylor) Schimp.

This variety has been considered as a distinct species in many manuals (Frey et al., 2006; Frahm, 2009; Hedenäs et al., 2014). Its first and only locality in Estonia is in Pärnu Co., Kihnu Island, Tõnu manor in the centre of island, dry boreal forest on a slope, on the base of a tree trunk $\left(58.0994^{\circ} \mathrm{N} 23.9744^{\circ} \mathrm{E}\right)$, leg. M. Leis 30 May 2015, det. M. Leis, 15 March 2016 (TAA5005189). The spreading of this variety to the mainland of Estonia might be difficult since it has an oceanic distribution in Europe (Dierßen, 2001). The variety can grow both on tree bark and on rocks (Hedenäs et al., 2014).

OXYRRHYNCHIUM schleicheRI (R. Hedw.) Röll. [Schleicheri nokkrood]

1st loc.: Rapla Co., Raikküla District, Jalase village, karst-area Tiidu-Tõnise, on the shaded side of a limestone plate $\left(58.9673^{\circ} \mathrm{N} 24.6292^{\circ} \mathrm{E}\right)$, leg. M. Leis, 06 May 1993, det. M. Leis 12 Jan 2017 (TAA5005230); 2nd loc.: Võru Co., Haanja District, Luutsniku village, Oxalis-Myrtillus spruce forest, on the bark of an aspen snag $\left(57.6294^{\circ} \mathrm{N}\right.$, $\left.26.9560^{\circ} \mathrm{E}\right)$, leg. P. Lõhmus 16 Sep 2016, det. M. Leis, L. Kannukene 24 Jan 2017 (TAA5005229).

This species is rather similar to O. hians, but characteristic features are underground stems, and twisted leaf tips (Atherton et al., 2010). O. schleicheri grows on moist shaded roadsides or river banks in forests (Hedenäs et al., 2014). This species is widely spread in western and southern Europe, being rarer in the north (Blockeel et al., 2014). In our neighbour countries it occurs in Latvia and Lithuania, but is absent from Finland (Hodgetts, 2015). In Sweden it has been evaluated as a vulnerable species in 2010 (Hedenäs, 2014: http:/ /artfakta.artdatabanken. se/taxon/634).
Sphagnum Affine Renauld \& Cardot [sarnasturbasammal]

1st loc.: I-Viru Co. Niinsaare bog, mire forest, on a ditch bank together with $S$. papillosum $\left(59.2533^{\circ} \mathrm{N} 27.5519^{\circ} \mathrm{E}\right)$, leg. K. I. Flatberg, M. O. Kyrkjeeide, 17 Aug 2012, det. K. I. Flatberg (TRH: B120298/1).

We have inspected also several TU specimens collected from the same region to find $S$. affine in between other Sphagnum mossess. One specimen of S. papillosum (TU168621) was even collected at the same time from the same bog, but no shoots of $S$. affine were found.

Sphagnum affine Renauld \& Cardot and $S$. austinii Sull. are the two European species in the S. imbricatum complex (e.g. Flatberg, 2013), and they were formerly considered to be a part of the intraspecific variation within $S$. imbricatum Hornsch.ex Russow (Flatberg, 1984). S. imbricatum is restricted in its distribution to East Asia and has a few records from Alaska. All specimens of earlier S. imbricatum records in Estonia have been identified as $S$. austinii for now.

Sphagnum affine grows in transitional poor and intermediate fen habitats forming low hummocks and lawns, often in mixture with $S$. papillosum. S. affine is more common in Europe compared to $S$. austinii, nevertheless it is missing in our neighbouring countries (Hodgetts, 2015). In Estonia it was found growing in a poor fen in East-Estonia, whereas S. austinii occurs in western part of Estonia, inhabiting hummocks in more nutrient rich bog margins.

SyNTRICHIA LATIFOLIA (Bruch ex Hartm.) Huebener [laialehine karvkeerik]

1st loc.: Harju Co., Kuusalu Distr., Valgejõgi at Nõmmeveski, on muddy soil below a rock at the base of a south-exposed slope of a ravine $\left(59.5075^{\circ} \mathrm{N} 25.7961^{\circ} \mathrm{E}\right)$, leg. H. J. During, 1 Aug 2003, det. H. J. During 17 Feb 2017 (During no 03813, duplicate: TU169845). A few muddy plants were collected growing close to the river, together with an unidentified tuber-bearing Bryum and Fissidens gracilifolius. The plants lacked the characteristic gemmae which are usually abundant on the leaves, but the leaf shape, cell size and papillosity, cross section of the costa, and the locally markedly red colour of the cell walls in reaction to $\mathrm{KOH}$ were decisive. Syntrichia latifolia is widely distributed in temperate Europe and also occurs in the Caucasus, Tur- 
key and western North America (Smith, 2004; Mishler, 2007). In Eastern Europe it is rare and endangered in many countries, including Latvia and Poland (Hodgetts, 2015). In Scandinavia it is almost restricted to Denmark and the southern parts of Norway and Sweden; it has not yet been found in Finland (Hallingbäck et al., 2008). The collection site is quite characteristic for the species: it usually grows on muddy tree bases, rocks and soil in the flood zone of streams and rivers (Smith, 2004). Its main dispersal mechanism seems to be gemmae, as sporophytes are rare.

\section{ACKNOWLEDGEMENTS}

Dr. Lars Hedenäs is acknowledged for checking first identification of Hypnum andoi.

This work has been financed by Estonian Ministry of Education and Research through the state program for scientific collections, the Centre of Excellence EcolChange and projects IUT34-7 and IUT20-29.

\section{REFERENCES}

Atherton, I., Bosanquet, S., Lawley, M. (eds.). 2010. Mosses and liverworts of Britain and Ireland - $a$ field guide. British Bryological Society. Latimer Trend \& Co. Ltd. Plymouth, pp. 770.

Blockeel, T. L., Bosanquet, S. D. S., Hill, M. O., Preston, C. D. 2014. Atlas of Britich and Irish Bryophytes. Vol. 2. Mosses. The British Bryological Society. Pisces publications, pp. 505.

Dierßen, K. 2001. Distribution, ecological amplitude and phytosociological characterization of European bryophytes. Bryophyt. Biblioth. 56: 3-289.

eElurikkus. http://elurikkus.ut.ee/ Accessed 10 March 2017.

Flatberg, K. I. 1984. A taxonomic revision of the Sphagnum imbricatum complex. Det Kongelige Norske Videnskabers Selskabs Skrifter 3: 1-80.

Flatberg, K. I. 2013. Norges torvmoser. Akademika forlag, Trondheim.
Frahm, J.-P. 2009. A preliminary study of the infraspecific taxa of Hypnum cupressiforme in Europe. Archive for Bryology 40: 1-10.

Frey, W., Frahm, J.-P., Fischer, E., Lobin, W. 2006. The liverworts, mosses and ferns of Europe. Gustav Fischer Verlag, Heidelberg.

Girgensohn, G. K. 1860. Naturgeschichte der Laubund Lebermoose Liv-, Ehst- und Kurlands. Arch. Naturk. Liv-, Ehst- und Kurlands 2(2): 1-488.

Hallingbäck, T., Lönnell, N., Weibull, H., von Knorring, P., Korotynska, M., Reisborg, C., Birgersson, M. 2008. Nationalnyckeln till Sveriges flora och fauna. Bladmossor: Kompaktmossor - kapmossor. Bryophyta: Anoectangium - Orthotrichum. ArtDatabanken, SLU, Uppsala.

Hedenäs, L., Reisborg, C., Hallingbäck, T. 2014. Nationalnyckeln till Sveriges flora och fauna. Bladmossor: Skirmossor - baronmossor. Bryophyta: Hookeria - Anomodon. ArtDatabanken, SLU, Uppsala.

Hodgetts, N. G. 2015. Checklist and country status of European bryophytes - toward a new Red List of Europe. Irish Wildlife Manuals 84: 1-125. https: / / www.npws.ie/sites/default/files / publications/pdf/IWM84.pdf

Leis, M., Kannukene, L. 2007. New Estonian Records: mosses. Folia Cryptog. Estonica 43: 69-72.

Mishler, B. D. 2007. Syntrichia. In: Flora of North America Editorial Committee (eds.) Flora of North America. Vol. 27: Bryophytes: Mosses, part 1. Oxford University Press. NY, pp. 618-627.

Smith, A. J. E. 1981. New combinations in European mosses. III. Pleurocarpous species. J. Bryol. 11(4): 605-607. https://doi.org/10.1179/ jbr.1981.11.4.605

Smith, A. J. E. 2004. The moss flora of Britain and Ireland. Cambridge University Press. https:/ / doi. org/10.1017/CBO9780511541858.

Stewart, N. 1995. Red Data Book of European Bryophytes. ECCB, Trondheim.

Vellak, K., Ingerpuu, N., Leis, M., Ehrlich, L. 2015. Annotated checklist of Estonian bryophytes. Folia Cryptog. Estonica 52: 109-127. https://doi. org/10.12697/fce.2015.52.14 
146 Folia Cryptog. Estonica 